\title{
From Class Politics to Classed Politics
}

\section{Vegard Jarness}

Oslo Metropolitan University, Norway

\section{Magne Paalgard Flemmen}

University of Oslo, Norway

\section{Lennart Rosenlund}

University of Stavanger, Norway

\begin{abstract}
Questions of political conflict have always been central to class analysis; changing political fault lines were a key argument in the debates about the 'death of class'. The ensuing 'cultural turn' in class analysis has shown how class continues to shape lives and experience, though often in new ways. In this article, we bring this mode of analysis to the political domain by unpacking how a multidimensional concept of class - based on the ideas of Bourdieu - can help make sense of contemporary political divisions. We demonstrate that there is a homological relation between the social space and the political space: pronounced political divisions between 'old' politics related to economic issues and 'new' politics related to 'postmaterial values' follow the volume and composition of capital. Importantly, the left/right divide seems more clearly related to the divide between cultural and economic capital than to the class hierarchy itself.
\end{abstract}

\section{Keywords}

cultural capital, economic capital, homology, Multiple Correspondence Analysis, political space, social space, stratification

\section{Corresponding author:}

Vegard Jarness, Centre for the Study of Professions, Oslo Metropolitan University, PO Box 4, St Olavs plass, 0130 Oslo, Norway.

Email: vegard.jarness@oslomet.no 


\section{Introduction}

Social conflict is a key theme in class analysis, not least in terms of the political orientations and agency of classes. In the heyday of sociological class analysis, class relations were largely regarded as giving rise to interest-based political orientations and class identities (see the accounts in Goldthorpe, 1996; Lockwood, 1995; Manza and Crowley, 2018). Although such accounts never went unchallenged, they started to be increasingly questioned as class identities failed to materialize and political fault lines became more complex, posing a considerable challenge to class analysis (Clark and Lipset, 1991; Pakulski and Waters, 1996). The ensuing 'cultural turn' in class analysis has dealt with class divisions by turning to Bourdieu (see the account in Devine and Savage, 2005).

Crucial to this is an understanding of the class structure as a multidimensional social space depicting the social distribution of cultural and economic capital, as well as the reflection of such in lifestyle differences and symbolic expressions of class. Although the idiom of class is rarely central to people's identities, research in this tradition has shown that identities and lifestyles nonetheless remain classed (see, for example, Bennett et al.,

2009; Savage et al., 2015).

However, with regard to the question of political divisions, this nascent reorientation has not progressed as far. In this article, we extend the 'culturalist' mode of class analysis from the domains of culture and lifestyle to the domain of politics by drawing on key concepts and approaches from Bourdieu (esp. 1984). In line with some recent contributions (De Keere, 2018; Flemmen and Haakestad, 2018; Harrits, 2013), we present an analysis of the relationship between the social space and the political space; that is, between the social distribution of cultural and economic capital on the one hand and the social distribution of political stances on the other.

Our case is Norway, a comparatively egalitarian, recognizably social-democratic society (Esping-Andersen, 2015). Norwegians themselves regard their country as particularly egalitarian, even compared to the neighbouring Nordic social democracies (Hjellbrekke et al., 2015); nonetheless, Norway can still be regarded as a class society. Although differences in income are compressed, differences in wealth are comparatively high and rising (Hansen, 2014). There is also mounting evidence of cultural class divisions rather similar to those found in other European countries (Flemmen et al., 2018). Norwegian politics share many basic characteristics with those of its Nordic neighbours: there is a variant of the 'frozen' five-party model, an influential labour movement and a social democratic party (the Labour Party) that 
dominated post-war governments (Lipset and Rokkan, 1967). Voter turnout is also relatively high (Pew Research Center, 2016). Arguably, however, due to the establishment of a socialist green party and a populist right-wing party in the 1960s and 1970s, 'new politics' has restructured the Norwegian political space, largely in line with a Western European pattern (Kriesi, 2010). Today, the Norwegian political system is dominated by three major parties: the Labour Party, the Conservatives and the Progress Party, supported by a handful of smaller ones, depending on the government in power: the Centre Party, the Christian Democratic Party, the Socialist Left Party, the communist Red Party and the Green Party.

\section{Bringing Politics Back to Class Analysis}

Classic class analysis has been geared towards mapping whether and how groups of individuals in similar class positions form realized classes, in the sense of collectives aware of their social and economic interests. Much attention has been devoted to the working class and its 'class consciousness' and political leanings (for an overview and discussion, see Lockwood, 1995). As class consciousness declined, and the connection between class and voting preferences was increasingly disrupted, this branch of class analysis lost much of its momentum. During the 1980s and 1990s, the concept of class was supposedly on its deathbed (Clark and Lipset, 1991; Pakulski and Waters, 1996). Such arguments were fuelled not only by particular understandings of what class is but also by particular expectations regarding how groups of individuals in various class positions would think and act. For detractors of class analysis, it seemed enough, at least for a while, to point to low levels of working-class consciousness or low levels of working-class voting for the political left.

In recent decades, however, cultural class analysis has restored the notion of class to the heart of mainstream sociology, arguing that class still structures social life in fundamental ways (see, for example, Bennett et al., 2009; Savage et al., 2013). Most of these contributions, however, do not share the understandings and expectations of classic class analysis. This new stream of research departs from it in several key respects. Two points are particularly relevant to the discussion in the present article. First, focus on the class/politics nexus has largely been abandoned in favour of a focus on the connection between class and lifestyle. Partly in response to the apparent decline in class politics, cultural class analysis has focused on whether and how lifestyles and identities still correspond to the class structure. Although there is some disagreement within this field of research (see the accounts in Friedman et al., 2015; Hazir and 
Warde, 2016), most studies point to a connection between class and lifestyle: tastes for food and drink, clothing, cars, literature, art and cinema are still clearly classed.

Second, the theorization of class has changed fundamentally (Bottero, 2004). Much previous research was primarily concerned with class as a purely economic concept; that is, the ways in which property and labour-market relations structure social inequality and conflict. In contrast, cultural class analysis emphasizes a multidimensional understanding of class. In addition to the economic aspect of class, it follows Bourdieu (1984) in regarding social class divisions as irrevocably social and cultural. A hallmark of this understanding is that social class divisions manifest themselves in the distribution of various forms of capital. According to Bourdieu's (1984: 128-129) model of the social space, social inequalities are not only structured vertically by the volume of capital but also horizontally by the composition of capital. The horizontal division implies that classes are further divided into class fractions in accordance with the relative preponderance of cultural and economic capital in people's capital portfolios.

Although promising, the 'cultural turn' omits three key points. First, a peculiar aspect of contemporary Bourdieusian class analysis - particularly within Anglophone sociology - is its neglect of whether and how political attitudes may also be classed (for notable exceptions, however, see De Keere, 2018; Harrits, 2013; Skjøtt-Larsen, 2012). Although a substantial part of Distinction endeavoured to demonstrate that political stances can be structured according to the model of the social space (Bourdieu, 1984: 397-465), contemporary discussions about Bourdieu's class model have focused almost exclusively on cultural consumption. In the following, we thus develop a cultural class analysis of politics that regards political attitudes as an aspect of lifestyle - or in Weberian terms, as people's worldview. We ask whether and how political divisions are structured according to the social space of contemporary Norway. Our analysis can also be regarded as part of the 'moral turn' in class analysis, where a rather diverse group of authors has highlighted the role of moral stances and worldviews while criticizing the narrow focus on cultural consumption and aesthetics in much research on contemporary class divisions (see, for example, Lamont, 1992; Sayer, 2005; Svallfors, 2006). According to this view, moral-political stances are deeply engrained in people's way of life and sense of self, for instance manifested in symbolic boundaries and judgements demarcating 'us' and 'them' as (real or imagined) symbolic communities.

Second, despite the widespread influence of Bourdieu's work, few scholars have applied his specific conceptualization of social class in terms of a social space. 
Remarkably, this model is absent even from the most extensive follow-up studies of Bourdieu's Distinction (Bennett et al., 2009), as well as from Savage et al.'s (2013) controversial 'new model of social class' inspired by Bourdieu. Here, we follow Bourdieu's (1984: 99-168) conceptualization of the social space as a multidimensional structure of economic and cultural capital. In the social space, there are no predefined class boundaries, allowing us to avoid the problem of assigning respondents to class categories. Crucially, we look at divisions along the dimension of capital composition that Bourdieu's followers and detractors alike too often overlook.

Third, the reception of Bourdieu's argument about the 'homology' between the social space and the spaces of lifestyles and political stances has involved some confusion. Bourdieu suggests that there is a correspondence, or structural similarity, between these analytically distinct social structures: 'the spaces $[\ldots]$ are organised according to the same fundamental structure, that of the social space determined by [the] volume and composition of capital' (Bourdieu, 1984: 208). He thus claims that there is a relationship between distinct structures and one cannot thus 'reduce the homologies between systems of differences to direct, mechanical relationships between groups and properties' (1984: 120), for instance between the working class and socialist economic stances. In our analysis, we model the two 'systems of differences' independently so that the thesis of homology can be assessed in a way that is more in line with its original conceptualization.

\section{Current Debates about Class and Politics}

Although there has been little interest in politics in cultural class analysis, the connection between class and politics remains a focal point of political sociology. Nonetheless, the theoretical-methodological approaches of political sociology have differed greatly from those of cultural class analysis. The typical model in early political sociology and class analysis was fairly straightforward: the working class was associated with the left, the middle class with the right. However, this pattern was disrupted by a differentiation of class relationships and changes in the political landscape. The 20th century saw an increasingly complex kaleidoscope of class positions and forms of political position-taking, as well as the increased influence of other factors, such as gender, age and ethnicity (Norris and Inglehart, 2019).

While some argued that this heralded the end of class society, others saw it as indicating more complex constellations. According to Giddens (1994: 90-91), the old 'politics of lifechances' - concerned with economic redistribution and related matters - was supplanted by a 
new 'politics of life-choices' - concerned with equality between the sexes, gay rights, environmentalism and so forth (see also Flanagan and Lee, 2003). Some saw this as indicative of a radical change in the nature of politics, with 'postmaterialist' politics supplanting of the old-fashioned clash between socialism and laissez-faire economic liberalism (Inglehart, 1990). This did not necessarily mean that classwas dead, rather that it was being buried alive by 'cultural voting' for new politics (Van Der Waal et al., 2007). According to Manza and Crowley (2018), the possibility that the political class divide has been 'flipped on its head' - with growing numbers of educated, middle-class people favouring new or traditional left-wing parties, while the 'new right' parties attract increasing numbers from the lower regions of the class structure - has revived interest in the class/politics nexus. At least to some extent, people's class positions continue to influence political attitudes and voting along the economic divide between the socialist left and the neo-liberal right (Evans and Tilley, 2017). The issue of new politics is, however, a hot point of contention; it is typically seen as requiring an explanatory variable of its own, often education or cultural capital (Houtman, 2001).

However, there are several fundamental problems with this linear mode of sociological analysis. We expand on Harrits' (2013) argument that political sociology has much to learn from the relational and multidimensional approach pioneered by Bourdieu. First, it makes little sense to contrast the explanatory power of education and cultural capital with that of social class, as the first plays an important role in constituting the second. In contrast, we model social class divisions as a social space where economic and cultural capital are entwined in a multidimensional structure. As we shall see, the two key forms of capital are distributed according to two principles that work independently: the overall volume of capital and its composition. Second, although the conceptual distinction between 'old' and 'new' politics is a useful one, they will not necessarily appear neatly as separate dimensions in empirical terms. To avoid such unfortunate theoretical preconstructions, we construct a political space inductively, assessing the ways in which position-taking in both types of political topics may be structurally intertwined.

\section{Data and Methods}

To investigate the connection between class and politics, we use Specific Multiple Correspondence Analysis and Euclidean classification (Agglomerative Hierarchical Classification with Ward's criterion) (Le Roux and Rouanet, 2004). We proceed by constructing two spaces - one social, one political - using separate correspondence analysis 
procedures. We then cluster the political space, allowing us to compare the structures of the two spaces by projecting the political clusters onto the social space. This offers the advantage of providing a strict assessment of the homology thesis because it deals directly with whether the structures are actually similar. It also respects the autonomy of social class relations and political differentiation, treating neither as a simple 'dependent' variable.

We use the 2011 round of Norsk Monitor ('Norwegian Monitor'), carried out by the market research organization, Ipsos MMI.1 Respondents were selected by simple random sampling from telephone directories and recruited by telephone calls. An interviewer asked introductory questions and then most of the survey took place through self-completed questionnaires. The response rate for the telephone interviews was approximately $25 \%$ and $10 \%$ filled in and returned the questionnaires (3980 respondents). As one might expect from this relatively low response rate, the resulting sample was sociodemographically skewed (respondents with low levels of capital were underrepresented). In earlier work, we have experimented with correcting for this by using weights (see the results in Flemmen et al., 2018) but it remains unclear how well this works with Multiple Correspondence Analysis (MCA). We report the results of unweighted analyses, though these are very similar to the results when using weights.

To construct the social space, we use 14 questions as indicators of economic and cultural capital. These variables and their contributions are shown in Table 1. We have used a wide range of fairly self-explanatory indicators of economic capital. For cultural capital, we use measures of the embodied, the institutionalized state and the objectified state (Bourdieu, 1986). We construct embodied cultural capital by using two questions that tap into the social milieu that shapes habitus: the first about the highest level of parental education and the second about the degree to which the respondent grew up in a 'cultured' home, surrounded by books, music, art and cultural interests. We construct institutionalized cultural capital by using respondents' own education levels and their field of education; this allows us to distinguish cultural capital of the 'scientific or technical type' from other manifestations of cultural capital. We construct objectified cultural capital by noting the number of books the respondent has read over the last year. We supplement this with occupation; this taps into both forms of capital as we single out occupations that are especially reliant on institutionalized cultural capital.(2)

Table 1. Questions used to construct the social space, with number of categories and contributions to main axes. 
The summed contributions indicate a balanced solution, meaning that neither form of capital dominates the principal axes. In constructing the political space, we focus on both 'old' and 'new' politics; that is, political attitudes related to the economy and 'post-material' values. The questions tap into core ideological issues such as egalitarianism and state control over business, as well as core issues of 'new' politics, such as immigration, environmentalism and Christian values. These questions have been recoded to remove the difference between 'strongly agree'/'strongly disagree' and 'agree'/'disagree'. The variables, number of categories and contributions to the primary axes are shown in Table 2.

\section{The Social Space}

With two dimensions, we reach a cumulated rate of modified eigenvalues of $59.7 \%$. The positions of all categories of our active variables - the cloud of categories - are shown in Figure 1.3 Both axes are shaped almost equally by economic and cultural capital so both axes reflect differences in the possession of both forms of capital.

The first axis, shown vertically in Figure 1, depicts differences in the volume of capital. At the bottom of the figure, the categories indicate low volumes of capital: low incomes, low levels of education and parental education, little or no savings in banks or investment funds, an upbringing in a home where there was little interest in culture, no holiday home or second home and a current home of a low to moderate estimated financial value. Moving upwards in the space, the total volume of cultural and economic capital increases. At the top there are high incomes, substantial savings in banks and investment funds, expensive homes, high levels of respondents' and parents' education and an upbringing in a home where there were books, music and culture generally.

The second axis, shown horizontally, is an axis of capital composition. Those richest in cultural capital are to the left of the map: they grew up in a 'cultured' home and have high levels of education, as do their parents. On the right-hand side of the map, there are their opposites, those rich in economic capital: they have the highest incomes, considerable savings in banks and funds, valuable homes and holiday homes and other properties. Moving from left to right in the space, the relative preponderance of cultural capital decreases, while relative economic capital increases.

\section{The Political Space}


With two axes, we reach a cumulated rate of modified eigenvalues of $82.1 \%$. Both axes can be considered general axes, since they are shaped more or less equally by variables for 'new' and 'old' politics. This means that there is not one axis for old politics and one for new. Figure 2 shows the cloud of categories. Axis 1 (horizontal) appears to be a generalized 'left versus right' axis, fusing aspects of old and new politics. On the left-hand side of the figure, there are stances associated with left-wing politics in Norway: opposition to privatization and private schools/hospitals, the belief that full employment is best ensured by state control and opposition to letting businesses decide too much. There is also disagreement with the assertion that children should obey their parents and that domestic problems should be solved first. There is agreement that overseas development aid should be increased and that immigration culturally enriches the nation.

Table 2. Questions used to construct the political space, with number of categories and contributions to main axes.

To the right of the map, we find the opposite views: there is support for privatization and private schools and hospitals and agreement that inequalities are small enough already, that businesses should decide more and that taxes should not be increased to pay for more public services. The role of new politics emerges in the views that domestic problems should be solved first, overseas aid should be decreased and immigrants' way of life does not 'fit' in Norway.

Axis 2 (vertical) crosscuts the more established 'left versus right' axis and can tentatively be dubbed a 'liberal versus traditional' axis. Towards the top of the figure, there is disagreement with a range of conservative-traditional ideals, for example that tried and tested ways are better than new ones, that certain opinions should be banned and that children should obey their parents. There is also a typical liberal ideal: that immigrants' way of life enriches society. There are also some typically liberal economic views: that inequalities are small enough, that inequalities in income in particular are too small and that social welfare should be reduced.

At the bottom of the figure, a more traditionalist opposition to these views can be found: there is agreement that tried and tested ways are better than new ones, that certain opinions should be banned and that immigrants' way of life does not 'fit' in Norway. There is also agreement that overseas aid should be decreased and that domestic problems should be solved first. There are also some traditional social-democratic attitudes: there is agreement that 
inequalities are too large, that full employment is best obtained by state intervention and that spending on social welfare should be increased. There is also opposition to privatization. By reading the map as a whole, we can retrace the dimensions of old and new politics, intertwined along the diagonals of the space. The upper-left quadrant corresponds to a liberal 'new left' fraction, the upper-right to a more typically right-wing view of economic issues, the lower-right is more typically 'new right' with authoritarian and anti-immigrant views and the lower-left quadrant is more 'old left' with an emphasis on traditional social-democratic economic policies.

Figure 1. The social space, cloud of categories.

\section{Inspecting Homologies}

To compare the structures of the two spaces, we conduct a Euclidean classification of the political space (Agglomerative Hierarchical Clustering using Ward's criterion) on the axes of the space. Clustering on all dimensions of the space means that we allow for suboppositions from lower-order axes to influence the clusters on a par with the main axes of the MCA. In this way, the analysis detects patterns that might have been 'lost' in the interpretation of the MCA maps.

Six clusters are optimal in terms of both intra- and inter-cluster inertia. The positions of these clusters in the political space are shown in Figure 3. We use heuristic names for the clusters, based on the detailed interpretation that follows. For the sake of interpretation, we look at how characteristic the clusters are in terms of the categories used to construct the political space. In so doing, it becomes clear that the clusters reflect the main oppositions of the space, while bearing witness to the importance of sub-oppositions related to more specific political points of contention. Table 3 shows the overrepresented categories in each cluster, based on test-values exceeding the $2.5 \%$ threshold, as calculated in SPAD.

Figure 2. The political space, cloud of categories.

To the far-left of Figure 3, we find the first cluster dubbed the liberal left $(12.2 \%$ of respondents). These respondents are highly distinctive in their views of new politics. They are most distinct in agreeing that overseas aid should be increased. They also agree that environmental protection should be increased and that immigrants' culture enriches society but 
disagreed that children should obey their parents. As we can see from Figure 3, the cluster is not in a distinct position along the second axis of the space.

The second cluster - dubbed the centre left $(30.5 \%)$ - is located close to the first one but is markedly less drawn to the left pole of Axis 1 and slightly more drawn to the upper pole of Axis 2. Their most distinctive stances are concerned with both old and new politics and they have typically centre-left stances: they agree that Norway should retain overseas aid at its current level, that private schools should not be allowed and that there should not be too much economic regulation.

Moving to the bottom of the space, and at a neutral position along Axis 1, there is the third cluster, dubbed social democratic (8.4\%). These respondents are highly distinctive in their view that Norway should expand its social welfare system. They also believe that inequalities in income are too large and should be reduced and that full employment is best ensured by a strong state.

The fourth cluster is in the upper right-hand corner of the figure at the extremes of both axes. This cluster is consistently right-wing on economic issues. It stands out in the view that inequalities in income are too small. This cluster has been dubbed the anti-egalitarian right (5.2\%). Their stances are also distinct in other issues of old politics: they believe that inequalities are small enough and that social welfare should be reduced but disagree that full employment is best ensured by a strong state; however, they agree that businesses should decide matters of their own development.

Figure 3. Clusters of political position-taking in the political space.

Table 3. Characterization of clusters derived from Euclidean classification of the political space.

We have dubbed the fifth cluster the religious conservatives (11.8\%). It is located close to the centre of the figure, drawn to some degree towards the lower pole of Axis 2 and the right pole of Axis 1. The most distinctive stances of these respondents are religious in nature. Their most characteristic stance is that there is too little emphasis on Christianity in contemporary society. They are also opposed to the idea that pre-marital sexual experience makes for a better marriage. They also believe in increased military spending and banning certain opinions. They also 
moderately support private schools and hospitals; this could perhaps be interpreted as support for faith-based schools, as these are privately owned in Norway but not run commercially.

The sixth and last cluster, dubbed the general right (31.8\%), is characterized by attitudes to both old and new politics: they agree that domestic problems should be solved first, there is too much economic regulation, overseas aid should be decreased, schools and hospitals should be privatized, taxes and welfare spending should be reduced and that immigrants' way of life does not 'fit' in Norwegian society.

The final step in our analysis is to project these clusters of political position-taking as supplementary points onto the social space. We will thus visualize the position of each political cluster in the social space, as though the social space were the independent variable and the political clusters the dependent one. This allows us to investigate the structural affinities between the social space and the political space. Figure 4 depicts the positions of the six clusters in social space and Table 4 shows the test-values of each cluster on each axis, with values $+/-$ 2.5 , signifying statistical significance at the $95 \%$ level.

In the upper left-hand quadrant of the social space - the region richest in cultural capital - we find the liberal left (significant on both axes) and the centre left (significant on capital composition). In the upper right-hand quadrant - among those richest in economic capital - we find the anti-egalitarian right (significant on both volume and composition). In the lower righthand quadrant - among those with low cultural capital but with a preponderance of economic capital - we find the general right (significant on both axes).

Finally, in the lower left-hand quadrant - among those with low economic capital but with a preponderance of cultural capital - we find the social democratic (significant on volume) and the religious-conservative clusters (not significant on either axis). The clusters thus map onto the social space in an intelligible way: left-wing stances are drawn towards cultural capital, whereas right-wing ones are more typically drawn towards economic capital. There are also three interesting points to note: first, the cluster most distinctly characterized by liberal stances in new politics occupies an extreme position in the culturally privileged region of the social space; second, the cluster most distinctly characterized by economic liberalism in old politics occupies an extreme position in the economically privileged region of the social space; third, the cluster most distinctly characterized by socialist stances in old politics occupies an extreme position in the region of social space endowed with low amounts of both forms of capital. This pattern is further underlined by the middle positioning of the politically 'moderate' clusters. 
When comparing the positioning of the clusters in the political space (Figure 3 ) and the social space (Figure 4), we can see that they are positioned in a very similar pattern in both spaces, indicating a homological relation. This means that distances in the social space are largely reflected in distances in political position-taking, though not perfectly. The positionings along the horizontal dimensions are almost identical, except clusters 4 and 6 have been reordered. The positionings along the vertical dimensions are also very similar, except for cluster 1 (drawn more towards the top in the social space) and the reordering of clusters 5 and 6.

Table 4. Test-values for clusters per axis of the social space.

Figure 4. Clusters of political position-taking in the social space.

To quantify this structural similarity, we have calculated the distances between the political clusters two-dimensionally in the social space. The results are shown in Table 5. The strongest social opposition is between the liberal left and the general right, above the threshold (1.0) for a large deviation (Le Roux and Rouanet, 2004), followed by the social democratic versus the anti-egalitarian right, bordering on a large deviation. Although the main pattern is straightforward - a clear homology between left versus right and cultural versus economic capital - there are also some interesting nuances. The third-largest distance (also bordering on a large deviation) is found between the liberal left and the social democratic cluster; that is, the 'new left' and the 'old left'. Thus, markedly left-wing economic views are associated with a lack of capital, while those richer in cultural capital, are more inclined to be left-leaning with an emphasis on 'new' value politics. Similarly, there is a notable distance between the antiegalitarian right and the general right-wing. Anti-egalitarianism is a form of right-wing positioning that is clearly 'rationally self-interested' for those rich in economic capital. The general right, more concerned with issues such as the cultural influence of immigration, are more associated with those endowed with considerably lower amounts of capital. This shows that the internal fractioning of both the political left and the political right is not just attitudinal, but also classed. 
Table 5. Two-dimensional distances between political clusters in social space, planes 1-2. Underlining indicates small deviations, italics indicate notable deviations and bold indicates large deviations.

\section{Concluding Discussion}

Our results reveal the persistence of class-structured political stances: political divisions reflect social distances. The results resemble the homology model proposed by Bourdieu (1984), as well as the findings of several other European studies using a similar methodology (see, for example, De Keere, 2018; Flemmen, 2014; Flemmen and Haakestad, 2018; Harrits, 2013; Skjøtt-Larsen, 2008). The validity of the model in Norway - a comparatively egalitarian society characterized by relatively compressed wage inequalities and pronounced egalitarian sentiments - suggests that the political aspects of contemporary class divisions are much more entrenched than is often assumed - and similar to those in other European countries.

However, our findings also diverge from those of mainstream political sociology that typically argues that old politics are structured by class and that other factors, such as education or status, structure new politics. Does this divergence reveal actual differences between empirical cases or can they be explained by differences in the theoretical-methodological design of the studies? We would highlight two points in favour of the latter explanation.

First, our approach contrasts with others that view class as a purely economic phenomenon that should be construed and analysed as a principle independently of cultural factors. When understanding class as a social space, it makes little sense to contrast the explanatory power of education and cultural capital with that of social class, as the former plays a crucial role in constituting the latter. Thus, differences in theoretical understandings of class directly influence the design of the analysis of the relationship between class and politics, as well as the interpretation of results. In this regard, our analysis lends credence to Bourdieu's rethinking of social class as a social space and that political divisions manifest themselves in the interplay between different forms of capital. In addition to vertical differentiation in the volume of capital, we have shown that the often neglected horizontal dimension differentiation in capital composition - is also salient.

Second, our approach to assessing the structuring of political stances diverges from conventional ones. In particular, our construction of the political space reveals some interesting results that challenge widely held assumptions about the relationship between 'old' and 'new' politics. While most scholars agree that both types are salient in contemporary society, they are 
typically theorized as separate dimensions in the political landscape and empirical inquiries thus tend to treat them separately. As our analysis clearly shows, old and new politics are intertwined along both dimensions of our political space. This highlights the dangers of the theoretical preconstructions implied by constructing separate measures for old and new politics, while demonstrating the fruitfulness of inductively mapping the specific configuration of these supposedly separate spheres of political stances.

Although our analysis resonates with Norris and Inglehart's (2019) recent account of a 'cultural cleavage' in contemporary politics, it also deviates from it. Their analysis lacks a proper assessment of whether and how contemporary political divisions correspond to the class structure. They explain the rise of authoritarian populism as a 'cultural backlash' - an 'authoritarian reflex' and 'a silent revolution in cultural values' guiding people's political preferences and voting behaviour. This process is seen as essentially psychological. According to them, the climate for the cultural backlash is first and foremost facilitated by historical developments towards post-materialist values. Although we do not deny these developments, our analysis suggests that both the economic cleavage (i.e. old politics) and the cultural cleavage (i.e. new politics) correspond systematically to the structure of social space. Although the specific manifestations and the strength of such structural correspondences may of course vary across contexts, our analysis shows that a proper assessment of the class-politics nexus employing a multidimensional concept of class is called for.

In Distinction, Bourdieu pointed to an interesting political alignment between those located in the lower regions of the social space and the cultural fraction of the upper region (both left-leaning) which could underpin a political alliance (Bourdieu, 1984: 438-440). Our analysis indicates that this must be qualified, especially in light of the pervasiveness of new politics. It is true that the cultural fraction of the upper class is markedly left-wing and can be regarded as aligning itself with the kind of politics traditionally deemed 'natural' for those with less capital. But the less well-off are clearly separated from their potential allies by their traditionalist position-taking, perhaps especially in the contentious issues of new politics. Judging by the hot controversies generated by questions of immigration, climate change and gender equality, this is perhaps not a gap easily bridged.

Indeed, as shown elsewhere (Jarness, 2018; Jarness and Hansen, 2018), class fractions rich in cultural capital, despite having ostensibly 'tolerant' political attitudes, harshly dismiss the lifestyles and political stances of those with low volumes of capital. Thus, liberal-left views are mobilized to draw symbolic boundaries 'downwards' in social space, rather similar to the 
ways in which cultural tastes are used. This may hinder political alignment between the lower regions of the social space and the cultural fraction of the upper region. Moreover, the economic fraction of the upper region of the social space are united with the lower regions in their contempt for the intellectual radicalism, liberalism and 'know-it-all' attitude of those regarded as 'the cultural elite'. This particular type of anti-elitism, it seems, is an integrated part of the lifestyle and worldview of both regions of the social space. This suggests that it is not the cultural but the economic fraction of the upper class that is symbolically closest to the lower region, as is supported by analyses of cultural tastes in the social space (Flemmen et al., 2018). This alignment might help explain why 'the new right parties [are] attracting significant blocs of poor and working- and lower-middle class citizens' (Manza and Crowley, 2018: 367).

\section{Funding}

This research received no specific grant from any funding agency in the public, commercial or not-for-profit sectors.

\section{Notes}

1. The data have been acquired from Ipsos by the Prism project, a joint research project on social change, carried out by University of Stavanger and International Research Institute of Stavanger (IRIS).

2. Occupation taps into cultural capital in the sense that many occupations, in particular those associated with the upper regions of the class structure, require educational qualifications. It also taps into economic capital in the sense that wages are unequally distributed in the occupation

structure, making a specific occupation an indicator of income.

3. In our visual representations, we sometimes display axes in reverse order, and/or show the first axis vertically. This is to ease the interpretation and comparison of graphs and involves no tampering with the analysis.

\section{References}

Bennett T, Savage M, Silva EB, et al. (2009) Culture, Class, Distinction. London: Routledge. Bottero W (2004) Class identities and the identity of class. Sociology 38(5): 985-1003.

Bourdieu P (1984) Distinction: A Social Critique of the Judgement of Taste. Cambridge, MA: Harvard University Press. 
Bourdieu P (1986) The forms of capital. In: Richardson J (ed.) Handbook of Theory and Research for the Sociology of Education. New York: Greenwood, 241-258.

Clark TN and Lipset SM (1991) Are social classes dying? International Sociology 6(4): 397410.

De Keere K (2018) Political distinction: Searching for a structural similarity between class and politics in Flanders (Belgium). European Societies 20(3): 375-400.

Devine F and Savage M (2005) The cultural turn, sociology and class analysis. In: Devine F, Savage M, Scott J, et al. (eds) Rethinking Class: Culture, Identities and Lifestyle. Basingstoke: Palgrave Macmillan, 1-23.

Esping-Andersen G (2015) Welfare regimes and social stratification. Journal of European Social

Policy 25(1): 124-134.

Evans G and Tilley J (2017) The New Politics of Class: The Political Exclusion of the British Working Class. Oxford: Oxford University Press.

Flanagan SC and Lee A-R (2003) The new politics, culture wars, and the authoritarianlibertarian

value change in advanced industrial democracies. Comparative Political Studies 36(3): $235-270$.

Flemmen M (2014) The politics of the service class: The homology of positions and positiontakings. European Societies 16(4): 543-569.

Flemmen M and Haakestad H (2018) Class and politics in twenty-first century Norway: A homology of positions and position-taking. European Societies 20(3): 401-423.

Flemmen M, Jarness V and Rosenlund L (2018) Social space and cultural class divisions: Forms of capital and contemporary lifestyle differentiation. British Journal of Sociology 69(1): 124153.

Friedman S, Savage M, Hanquinet L, et al. (2015) Cultural sociology and new forms of distinction. Poetics 53: 1-8.

Giddens A (1994) Beyond Left and Right: The Future of Radical Politics. Cambridge: Polity. Goldthorpe JH (1996) Class and politics in advanced industrial societies. In: Lee DJ and Turner BS (eds) Conflicts about Class: Debating Inequality in Late Industrialism. London: Longman, 196-208.

Hansen MN (2014) Self-made wealth or family wealth? Changes in intergenerational wealth mobility. Social Forces 93(2): 457-481. 
Harrits GS (2013) Class, culture and politics: On the relevance of a Bourdieusian concept of class in political sociology. The Sociological Review 61(1): 172-202.

Hazir IK and Warde A (2016) The cultural omnivore thesis: Methodological aspects of the debate. In: Hanquinet L and Savage M (eds) Routledge International Handbook of the Sociology of Art and Culture. Oxon: Routledge, 77-89.

Hjellbrekke J, Jarness V and Korsnes O (2015) Cultural distinctions in an 'egalitarian' society. In: Coulangeon P and Duval J (eds) Routledge Companion to Bourdieu's 'Distinction'. London: Routledge, 187-206.

Houtman D (2001) Class, culture, and conservatism reassessing education as a variable in political sociology. In: Clark TN and Lipset SM (eds) The Breakdown of Class Politics: A Debate on Post-Industrial Stratification. Washington, DC: Woodrow Wilson Center Press, 161-195.

Inglehart R (1990) Culture Shift in Advanced Industrial Society. Princeton, NJ: Princeton University Press.

Jarness V (2018) Viewpoints and points of view: Situating symbolic boundary drawing in social space. European Societies 20(3): 503-524.

Jarness V and Hansen ML (2018) Grønne grenser: Distinksjoner og likhetsidealer i den miljøbevisste middelklassen [Green boundaries: Distinction and egalitarianism in the environmentally aware middle class]. Norsk sosiologisk tidsskrift 2(3): 208-224.

Kriesi H (2010) Restructuration of partisan politics and the emergence of a new cleavage based on values. West European Politics 33: 673-685.

Lamont M (1992) Money, Morals, and Manners: The Culture of the French and American Upper-Middle Class. Chicago, IL: University of Chicago Press.

Jarness et al. 899

Le Roux B and Rouanet H (2004) Geometric Data Analysis: From Correspondence Analysis to Structured Data Analysis. Dordrecht: Kluwer.

Lipset SM and Rokkan S (1967) Party Structure and Voters' Alignments. New York: Free Press.

Lockwood D (1995) Marking out the middle classes. In: Butler T and Savage M (eds) Social Change and Middle Classes. London: UCL Press, 1-12.

Manza J and Crowley N (2018) Class divisions and political attitudes in the 21st century. In: Albarracín D and Johnson BT (eds) Handbook of Attitudes, Volume 2: Applications. London: Routledge, 367-407. 
Norris P and Inglehart R (2019) Cultural Backlash: Trump, Brexit, and Authoritarian Populism. Cambridge: Cambridge University Press.

Pakulski J and Waters M (1996) The Death of Class. London: SAGE.

Pew Research Center (2016) U.S. voter turnout trails most developed countries. Available at: http://www.pewresearch.org/fact-tank/2016/08/02/u-s-voter-turnout-trails-most-developed countries/ (accessed 8 February 2017).

Savage M, Cunningham N, Devine F, et al. (2015) Social Class in the 21 st Century. London: Penguin.

Savage M, Devine F, Cunningham N, et al. (2013) A new model of social class? Findings from the BBC's Great British Class Survey Experiment. Sociology 47(2): 219-250.

Sayer A (2005) The Moral Significance of Class. Cambridge: Cambridge University Press. Skjøtt-Larsen J (2008) Klasse, kultur og politik: Social differentiering i det postindustrielle Aalborg [Class, culture and politics: Social differentiation in postindustrial Aalborg]. Aalborg: Aalborg University.

Skjøtt-Larsen J (2012) Cultural and moral class boundaries in a Nordic context: Findings from a city in Denmark. European Societies 14(5): 660-683.

Svallfors S (2006) The Moral Economy of Class. Stanford, CA: Stanford University Press.

Van Der Waal J, Achterberg P and Houtman D (2007) Class is not dead, it has been buried alive: Class voting and cultural voting in postwar western societies (1956-1990). Politics \& Society 45: 403-426.

Vegard Jarness is a researcher at the Centre for the Study of Professions, Oslo Metropolitan University. His research interests include social class, cultural stratification and political divisions. Recent publications have appeared in British Journal of Sociology, European Societies and Poetics.

Magne Paalgard Flemmen is Associate Professor at the Department of Sociology and Human Geography at the University of Oslo. His research interests lie in the areas of class analysis, social stratification and inequality. His work focuses on the theory and model of social space, as well as the cultural and political components of class divisions. Recent publications have appeared in American Sociological Review, Sociology, European Societies and British Journal of Sociology. 
Lennart Rosenlund is Professor Emeritus at University of Stavanger. His research interests include social class, cultural stratification and socio-spatial divisions. Recent publications have appeared in British Journal of Sociology, Sociological Review and Bulletin de méthodologie sociologique. 
Tables and figures

Table 1: Questions used to construct the social space, with number of categories and contributions to main axes

\begin{tabular}{lccc} 
& Number of & Axis & Axis \\
& categories & $\mathbf{1}$ & $\mathbf{2}$ \\
\hline Cultural capital & $\mathbf{2 6}$ & $\mathbf{4 3 . 2}$ & $\mathbf{4 9 . 5}$ \\
\hline Grew up in a cultured home & 5 & 4.1 & 9.0 \\
Parents' education & 4 & 5.6 & 5.7 \\
Respondent's education & 4 & 17.6 & 5.3 \\
Field of education & 6 & 9.6 & 19.3 \\
Military education & 2 & 2.5 & 1.6 \\
Books read per year & 5 & 3.9 & 8.6 \\
\hline Economic capital & & & \\
\hline Gross income & $\mathbf{3 5}$ & $\mathbf{4 1 . 8}$ & $\mathbf{3 2 . 8}$ \\
Own or rent house & 8 & 15.5 & 7.1 \\
Bank deposits & 3 & 1.3 & 4.3 \\
Fund savings & 5 & 4.1 & 3.0 \\
Price of home & 4 & 3.7 & 4.6 \\
Holiday home & 5 & 11.8 & 1.0 \\
Additional properties & 3 & 3.9 & 3.4 \\
Number of cars & 2 & 1.1 & 1.4 \\
\hline Occupation & 5 & 0.5 & 7.9 \\
\hline
\end{tabular}

Table 2: Questions used to construct the political space, with number of categories and contributions to main axes

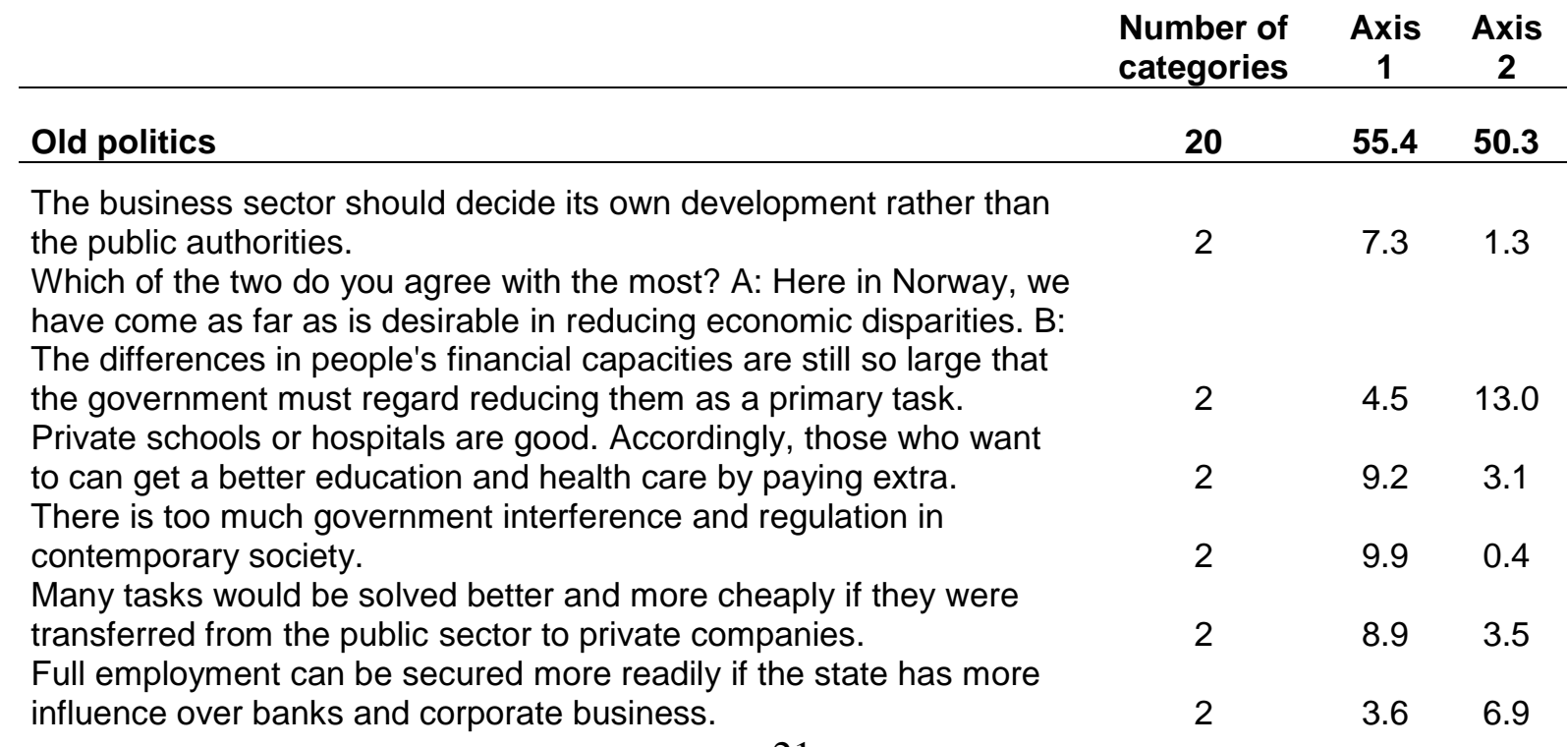


It is necessary to have high tax levels to maintain essential public services.

What do you think about the pay differences in Norwegian society today? Are they too big, are they reasonable or has the policy of equalization been taken too far so differences in pay are too small? Many believe that we have more than enough social security and should seek to limit it in the future, while others argue that we should maintain our social security systems and, if necessary, expand them. What's your opinion?

The tried and tested is usually better than new-fangled experiments. Sexual experience before marriage helps make the marriage happier.

We should solve the problems in our own country before spending money helping people overseas.

2

$0.0 \quad 1.5$

There are many opinions that should never be allowed on the radio and television.

Do you think the Christian faith and its practice have a place that is too large, just right or too small in Norwegian society today?

To me, respect for law and order is of paramount importance.

A says: Immigrants contribute to greater cultural diversity in Norway, with exciting new foods, music, art, etc. B says: Immigrants' way of life does not fit in Norway. Foreign customs are a disadvantage to the surroundings and can be a threat to our national culture. Do you think that allocations to the Norwegian military should be increased, maintained at current levels or reduced?

Do you think that allocations to development aid/Norwegian aid to

$\begin{array}{lll}2 & 0.3 & 0.1\end{array}$
developing countries should be increased, maintained at current levels or reduced?

Is it important to strengthen environmental protection?

The most important thing that children should learn is obedience to and respect for their parents.

\begin{tabular}{lcc}
2 & 7.2 & 8.8 \\
3 & 3.1 & 1.5 \\
& & \\
3 & 10.1 & 6.5 \\
2 & 5.1 & 0.0 \\
2 & 4.8 & 5.4 \\
\hline
\end{tabular}


Table 3: Characterization of clusters derived from Euclidean classification of the political space

\begin{tabular}{|c|c|c|c|c|c|}
\hline $\begin{array}{l}\text { Cluster } 1 \\
\text { Liberal left }\end{array}$ & & $\begin{array}{l}\text { Cluster } 2 \\
\text { Centre left }\end{array}$ & & $\begin{array}{l}\text { Cluster } 3 \\
\text { Social democratic }\end{array}$ & \\
\hline Characteristic categories & Overrep. & Characteristic categories & Overrep. & Characteristic categories & Overrep. \\
\hline Increase aid & 5.8 & Keep aid & 1.7 & Expand welfare & 9.7 \\
\hline Decrease military spending & 2.7 & Not too much regulation & 1.5 & $<>$ Business & 2.1 \\
\hline Strengthen environm. protection & 2.2 & Not private schools/hospitals & 1.5 & $<>$ Christianity & 1.6 \\
\hline Full employment, state control & 2.0 & Not domestic problems first & 1.4 & Too big wage inequalities & 1.4 \\
\hline Children not obey parents & 2.0 & No privatization & 1.4 & Full employment, state control & 1.3 \\
\hline Too much Christianity & 2.0 & $<>$ Aid & 1.4 & Inequalities should be reduced & 1.2 \\
\hline Not respect law and order & 1.9 & Children not obey parents & 1.3 & Domestic problems first & 1.2 \\
\hline Not domestic problems first & 1.8 & Business not decide & 1.3 & No privatization & 1.1 \\
\hline Not too much regulation & 1.7 & Keep welfare & 1.3 & Children obey parents & 1.1 \\
\hline No privatization & 1.6 & Immigrants cultural enrichment & 1.3 & & \\
\hline Not private schools/hospitals & 1.6 & High tax for public services & 1.3 & & \\
\hline Business not decide & 1.5 & <>Full employment, state & 1.3 & & \\
\hline Immigrants cultural enrichment & 1.5 & <>Sex. experience better & 1.3 & & \\
\hline High tax for public services & 1.4 & Just right Christian & 1.2 & & \\
\hline Too big wage inequalities & 1.3 & Strengthen environm. protection & 1.2 & & \\
\hline Inequalities should be reduced & 1.3 & <> Military spending & 1.2 & & \\
\hline Keep welfare & 1.3 & Keep military spending & 1.2 & & \\
\hline Not ban opinions & 1.2 & Inequalities should be reduced & 1.2 & & \\
\hline \multirow[t]{4}{*}{ Not old and tried better } & 1.2 & Full employment, state control & 1.2 & & \\
\hline & & Not ban opinions & 1.1 & & \\
\hline & & Not old and tried better & 1.1 & & \\
\hline & & Too big wage inequalities & 1.1 & & \\
\hline $\begin{array}{l}\text { Cluster } 4 \\
\text { Anti-egalitarian right }\end{array}$ & & $\begin{array}{l}\text { Cluster } 5 \\
\text { Religious conservative }\end{array}$ & & $\begin{array}{l}\text { Cluster } 6 \\
\text { General right }\end{array}$ & \\
\hline Too small wage inequalities & 19.1 & Too little Christian & 5.8 & Decrease aid & 2.1 \\
\hline Inequalities small enough & 2.9 & Not sex. experience & 2.1 & Immigrants way of life & 1.9 \\
\hline Reduce welfare & 1.9 & Increase military spending & 1.7 & Domestic problems first & 1.9 \\
\hline No high tax for public & 1.7 & Ban opinions & 1.4 & Not high tax for public services & 1.8 \\
\hline
\end{tabular}


Increase military spending

Business decide

Privatization

Private schools/hospitals

Too much regulation

Decrease aid

Not full employment

Not strengthen environment

Domestic problems first

Sex. experience better
<>Immigrants

Private schools/hospitals

Increase aid

Old and tried better

Immigrants way of life

Business decide

Privatization

Too much regulation

Keep welfare

Just right wage inequality

Children obey parents

Respect law and order
1.4 Reduce welfare

Private schools/hospitals

Too much regulation

Inequalities small enough

Privatization

Business decide

<> Christianity

Just right wage inequality

Old and tried better

Children obey parents

Increase military spending

Not strengthen environment

<>Immigrants

Just right Christian

Not full employment

$<>$ Inequalities

Ban opinions

Sex. experience better 
Table 4: Test-values for clusters per axis of the social space

\begin{tabular}{lcc}
\hline & $\begin{array}{c}\text { Axis 1: } \\
\text { Volume of } \\
\text { capital }\end{array}$ & $\begin{array}{c}\text { Axis 2: } \\
\text { Composition of } \\
\text { capital }\end{array}$ \\
\hline 1: Liberal left & 7.951 & -9.815 \\
2: Centre left & 1.786 & -6.626 \\
3: Social democratic & -6.367 & -1.426 \\
4: Anti-egalitarian right & $\mathbf{6 . 2 0 3}$ & $\mathbf{2 . 3 9 6}$ \\
5: Religious & & -1.475 \\
conservative & -2.300 & $\mathbf{1 4 . 1 8 6}$ \\
6: General right & -4.921 & \\
\hline
\end{tabular}

Table 5: Two-dimensional distances between political clusters in social space, planes 1-2. Grey font indicates small deviations, italics indicate notable deviations and bold indicates large deviations.

\begin{tabular}{lccccc}
\hline & $\begin{array}{c}\text { 1: } \\
\text { Liberal left }\end{array}$ & $\begin{array}{c}\text { 2: } \\
\text { Centre left }\end{array}$ & $\begin{array}{c}\text { 3: Social } \\
\text { democratic }\end{array}$ & $\begin{array}{c}\text { 4: Anti- } \\
\text { egalitarian } \\
\text { right }\end{array}$ & $\begin{array}{c}\text { 5: Religious } \\
\text { conservative }\end{array}$ \\
\hline $\begin{array}{l}\text { 1: Liberal left } \\
\text { 2: Centre left }\end{array}$ & 0.49 & & & & \\
$\begin{array}{l}\text { 3: Social } \\
\text { democratic }\end{array}$ & 0.93 & 0.48 & & & \\
$\begin{array}{l}\text { 4: Anti-egalitarian } \\
\text { right }\end{array}$ & 0.73 & 0.62 & 0.98 & & \\
5: Religious & & & & & \\
conservative & 0.70 & 0.21 & 0.29 & 0.70 & \\
6: General right & $\mathbf{1 . 0 8}$ & 0.64 & 0.57 & 0.70 & 0.49 \\
\hline
\end{tabular}


Figure 1. The social space, cloud of categories.

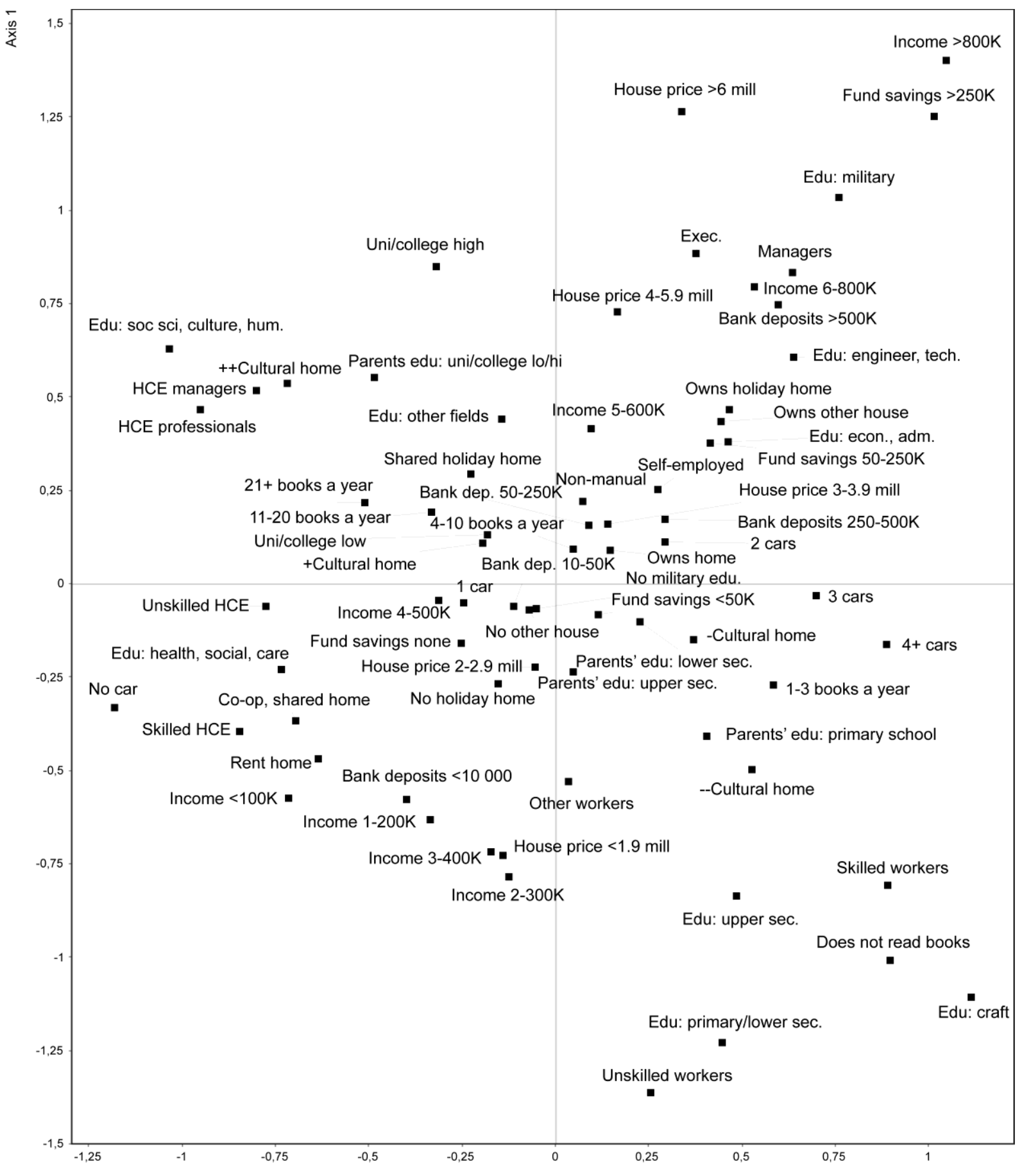

Axis 2 
Figure 2. The political space, cloud of categories.

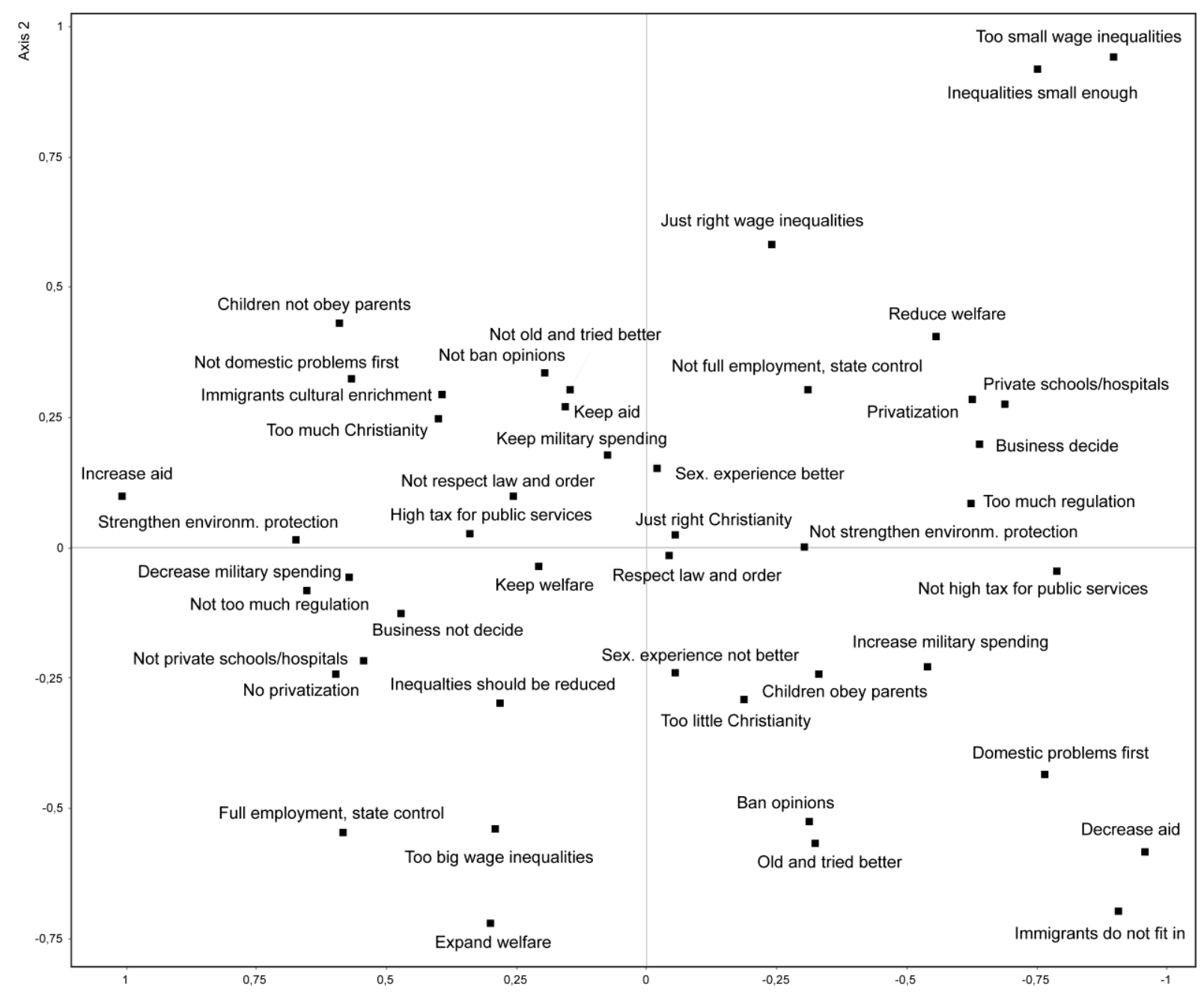

Axis 1 
Figure 3. Clusters of political position-taking in the political space.

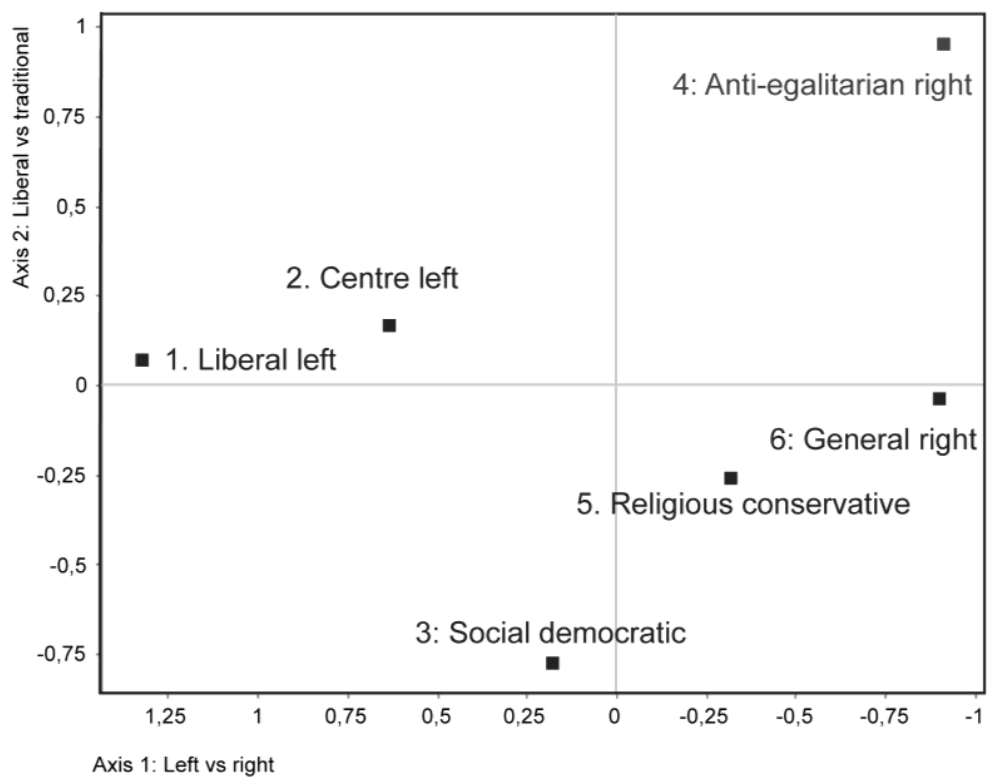


Figure 4. Clusters of political position-taking in the social space.

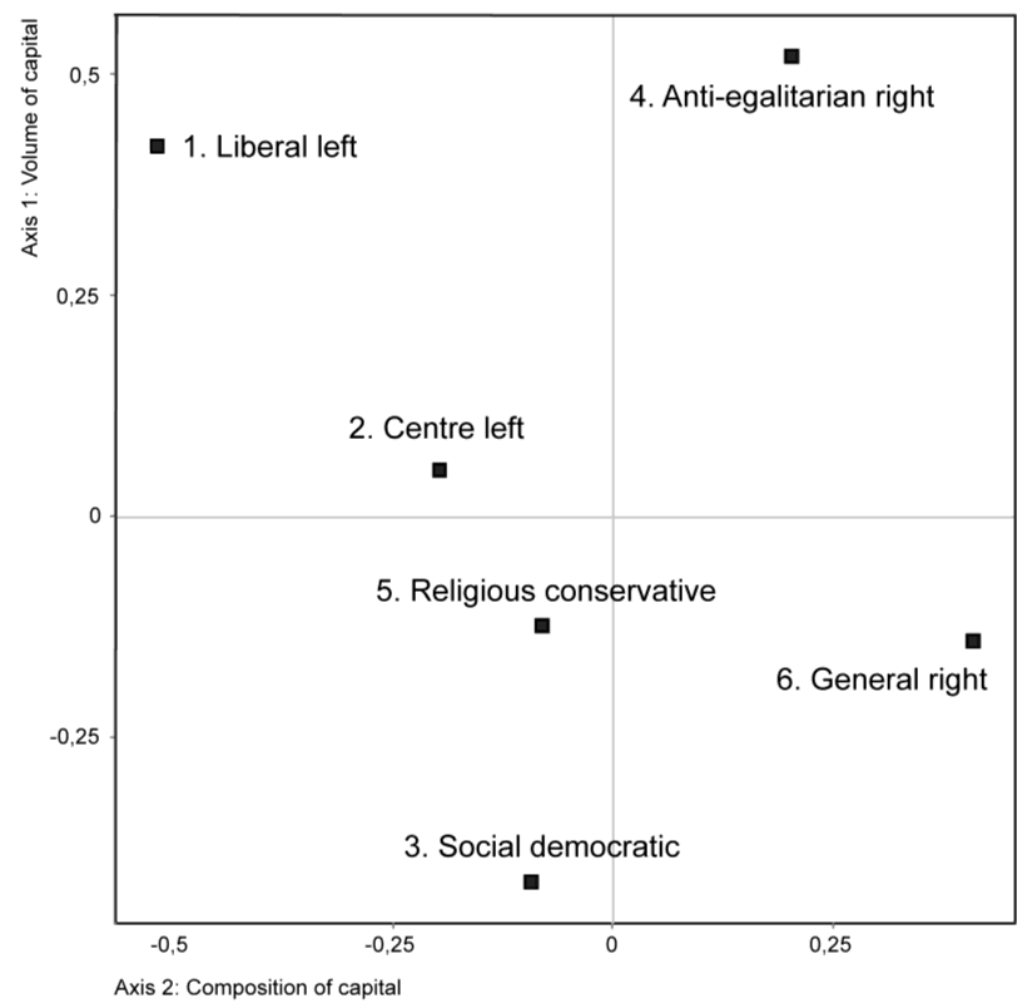

